\title{
Statistical analysis of Neogene sediment thickness deposited during the first transtensional and first transpressional evolutionary stages in the Bjelovar Sub-basin, Northern Croatia
}

\author{
Ana Majstorović Bušić \\ Sector for Geology and Reservoir Management, \\ Oil \& Gas Exploration and Production, INA-Industry of Oil Plc
}

\begin{abstract}
The Bjelovar Sub-basin is situated in Northern Croatia and constitutes the southwestern branch of the Drava Basin. The Neogene-Quaternary sedimentary section can be subdivided into three megacycles, which are separated by regional unconformities. The data analyzed in this study are related to the first megacycle, which is characterized by a tectonic-erosional unconformity above the Neogene basement (electric log, abbr. e-log marker Pt or Tg); its top is the regional e-log marker Rs7. It is generally assumed that the Rs7 marker separates Sarmatian and Pannonian sediments and indicates the period just after the first transtensional and first transpressional events. The youngest e$\log$ marker, Rs5, represents the Lower/Upper Pannonian boundary (in Croatian stratigraphic nomenclature) and more generally the early period of the second transtensional event. The lithology of the Lower and Middle Badenian is characterized by coarse and medium-grained sediments, while the Upper Badenian to Lower Pannonian section is dominantly pelitic as a result of flattening of the eroded paleorelief, as well as of reduced amounts of fans and energy. Thickness maps for the stratigraphic intervals Pt/Tg-Rs7 (4.9 Ma) and Rs7-Rs5 (2.2 Ma) were statistically analyzed using a regular grid with individual cells of $500 \times 500 \mathrm{~m}$. It is demonstrated that the first transpressional event in this sub-basin continued during the Lower Pannonian, causing a significant decrease of sediment thickness and a large unconformity in the east. Statistics based on histograms and averages confirmed that the first transtension and first transpression can be clearly distinguished by the presented methodology.
\end{abstract}

Key words: Bjelovar Sub-basin, Pannonian Basin System, Croatia, Miocene, transtension, transpression, statistics

Address: A. Majstorovic Bušic: Šubiceva 29, 10000 Zagreb, Croatia, e-mail: ana.majstorovic@ina.hr

Received: August 28, 2011; accepted: December 16, 2011 


\section{Introduction}

The geologic evolution of the Croatian part (CPBS) of the Pannonian Basin System (PBS) has been described in several papers, e.g. Tari 1994; Csontos et al. 2002; Saftic et al. 2003. This paper discusses the effects of the first transtensional and transpressional events on sediment thickness changes, determined by statistical analysis of regional thickness maps. The analytical targets were Middle and Upper Miocene sediments of the Bjelovar Sub-basin, which is located in the northern part of Croatia and constitutes the southwestern branch of the Drava Basin, covering approximately $2900 \mathrm{~km}^{2}$. This area is geologically and geographically separated from the Drava Basin by the uplift of the Bilogora Mountains in the Pliocene and Quaternary. The sub-basin margins are determined mostly by surface morphology and the surrounding mountains (Fig. 1): Mt. Kalnik to the northwest; the Bilogora Mountains to the northeast; Mt. Papuk, Mt. Ravna gora, and Mt. Psunj to the east and southeast; and Mt. Moslavacka gora to the south (Malvić 2011).

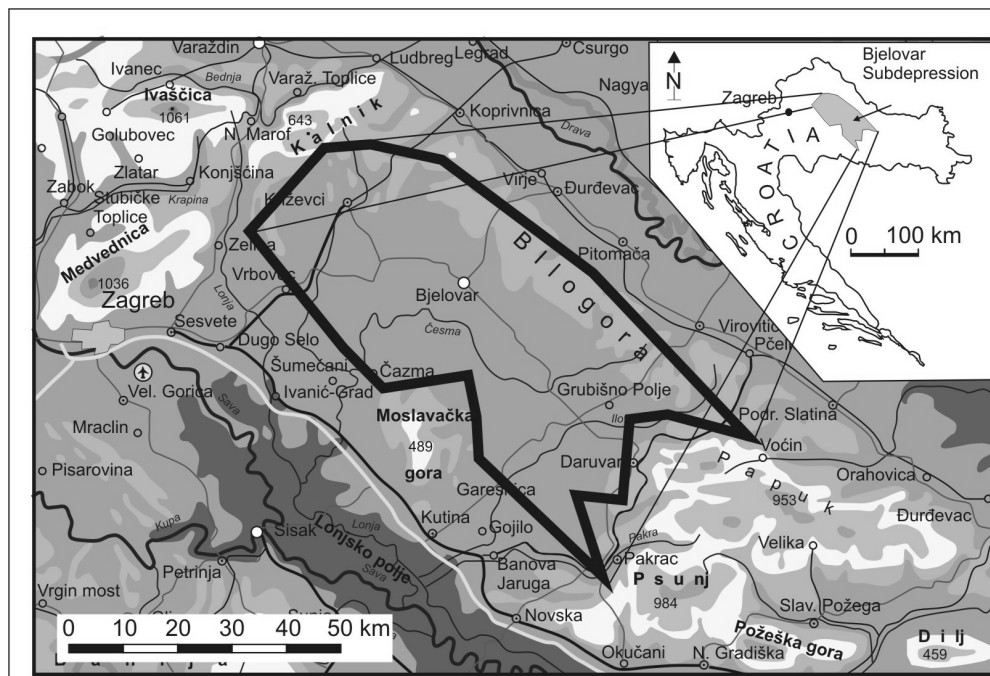

LEGEND:

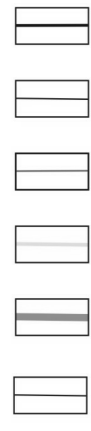

Important railroads

Other railroads

Roads

Highway

State border

Small rivers
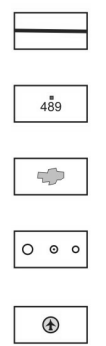

से
Large rivers

Altitude

Zagreb

(800,000 inhabitants)

Settlements $(25,000$ $50,000,5,000-25,000$ and $<5,000$ inhabitants)

International

airport

Area shown on Maps 1-11

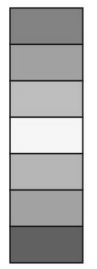

$1000-1500 m$ $750-1000 \mathrm{~m}$ $500-750 \mathrm{~m}$ $300-500 \mathrm{~m}$ 200 - $300 \mathrm{~m}$ $100-200 m$ 0 - $100 \mathrm{~m}$

Fig. 1

Geographic map of the Bjelovar Subbasin (after Malvić 2011) 
It has been assumed that the first (Sarmatian) transpressional event is reflected in shallowing and in changes of the thickness of sediments previously widely deposited during the first transtensional one (Badenian). This analysis helped to determine the local duration of the first transpressional event in the Bjelovar Subbasin, i.e., could it be traced only in the Sarmatian in the CPBS, as Malvić and Velić (2011) assumed, or does it have a different time span? Analyzed chronostratigraphic intervals yielded durations of 3.4 Ma for the Badenian, 1.5 Ma for the Sarmatian, and 2.2 Ma for the Lower Pannonian. Structural maps for the intervals Pt/Tg-Rs7 and Rs7-Rs5 were used (maps after Malvić 2011) for thickness analysis.

Royden (1998) and Rögl $(1996 ; 1998)$ documented the time intervals of different Miocene stages in the PBS, establishing a time scale used to categorize tectonic and sedimentation styles (Malvić and Velić 2010) in the CPBS. The maximum of the first transtensional event was in the Badenian (16.4-13.0 Ma). Carbonate and siliciclastic detritus was deposited in alluvial fan environments. Coarse-grained sediments were deposited in the proximal part, and medium and fine-grained sandstone in the middle or outer parts of the alluvial fans. The evolution of the environment was controlled by specifics such as the pre-Neogene basement erosion rate, stream power, and localized tectonics. During the Sarmatian (13.0-11.5 Ma) transtensional tectonics were replaced by transpression. The importance of alluvial fans significantly decreased because regression began (Malvić and Velić 2010). In the Early Pannonian (11.5-9.3 Ma) transpression ended and the second wave of transtensional tectonics assumed a dominant place in the entire PBS (Royden 1988), where widespread lacustrine and brackish environments existed.

\section{Geologic settings}

The sediments of the Neogene-Quaternary system in the southwestern part of the PBS are divided into three sedimentary megacycles, which are separated by regional unconformities (Velić et al. 2002; Velić 2007; Malvić and Velić 2011). The general time scale of different tectonic styles and environments is shown in Fig. 2 (Malvić and Velić 2011).

Although rare and locally terrestrial Early Miocene sediments can be found, the first megacycle is characterized by a heterogeneous lithological composition, consisting of marine syn-rift and early post-rift sediments of Middle Miocene age. The second depositional megacycle was active in the Late Miocene and is characterized by sandstone, marly sandstone, sandy marl, and marl lithofacies. The third megacycle is of Pliocene-Quaternary age and is composed of sand, clay, and gravel with some sporadic lenses of lignite or peat.

The analyzed intervals belong to the first (Badenian and Sarmatian Stages) and second (Lower Pannonian Stage) megacycle. Sedimentation, lithological compositions, and stratigraphic positions of Neogene and Quaternary sediments 


\begin{tabular}{|c|c|c|c|c|c|c|c|c|c|c|c|c|c|c|c|c|c|c|}
\hline \multicolumn{19}{|c|}{ Million of years in the past (Ma) } \\
\hline 19 & 18 & 17 & 16 & 15 & 14 & 12 & 11 & 10 & 9 & 8 & 7 & 6 & 5 & 4 & 3 & 2 & 1 & 0 \\
\hline \multirow{2}{*}{\multicolumn{2}{|c|}{$\begin{array}{l}\text { Ottnan- } \\
\text { gian }\end{array}$}} & Kar- & \multirow{2}{*}{\multicolumn{3}{|c|}{ Badenian }} & \multirow{2}{*}{$\begin{array}{l}\text { Sarma- } \\
\text { tian }\end{array}$} & \multicolumn{4}{|c|}{ Pannonian } & Pont & tian & \multirow{2}{*}{\multicolumn{3}{|c|}{ Pliocene }} & \multirow{2}{*}{\multicolumn{2}{|c|}{ Quaternary }} & \\
\hline & & \begin{tabular}{|c} 
pati- \\
an
\end{tabular} & & & & & & arly & & Late & Early & Late & & & & & & \\
\hline \multirow{2}{*}{\multicolumn{3}{|c|}{\begin{tabular}{|c|} 
Maybe sporadical \\
extensions in CPBS?
\end{tabular}}} & \multicolumn{3}{|c|}{$\begin{array}{c}\text { 1st transtensional } \\
\text { phase }\end{array}$} & $\begin{array}{l}\text { 1st trans- } \\
\text { pression }\end{array}$ & \multicolumn{5}{|c|}{$\begin{array}{l}\text { 2nd transtensional } \\
\text { phase }\end{array}$} & \multicolumn{6}{|c|}{$\begin{array}{c}\text { 2nd transpressional } \\
\text { phase }\end{array}$} & \\
\hline & & & \multicolumn{3}{|c|}{$\begin{array}{l}\text { Local inland } \\
\text { weathering and alluvial } \\
\text { fans mechanism }\end{array}$} & \begin{tabular}{|c|} 
Shallowing \\
and \\
salinity \\
reducing
\end{tabular} & \multicolumn{5}{|c|}{$\begin{array}{l}\text { Distant clastic source and } \\
\text { turbidite mechanism }\end{array}$} & \multicolumn{6}{|c|}{$\begin{array}{l}\text { Final structural forming, } \\
\text { migration of hydrocarbons, } \\
\text { eventually continental environment }\end{array}$} & \\
\hline
\end{tabular}

Fig. 2

Main tectonic and depositional events in the CPBS during the Neogene and Quaternary (from Malvić and Velić 2011)

have been determined from well and seismic data, especially the Middle and Lower Miocene sediments characterized by significant hydrocarbon potential in the entire Drava Basin (see Malvić 2003). The tectonic-erosional unconformity at the base of the Neogene is marked by e-log boundary Pt or Tg (sometimes written as $\mathrm{Pt} / \mathrm{Tg}$ ). The next e-log regional marker (or key bed) is Rs7. This boundary unit separates Sarmatian and Pannonian sediments, and was either deposited as a regional marl, or its absence represents an unconformity as a result of erosion caused by the first regional transpressional event, which generally ceased in the CPBS at the end of the Sarmatian (Malvić and Velić 2011). However, it is logical to assume that this (and other) boundaries between the evolutionary stages of the CPBS are not completely synchronous, and locally some stages could have been longer or shorter. The youngest analyzed e-log marker was Rs5, considered as a key regional thin, marly bed. It represents the top of the Lower Pannonian and generally belongs to the second transtensional event or to the second depositional megacycle.

In this paper two thickness maps (Malvić 2003, 2011) are analyzed. One represents the combined thickness of Badenian and Sarmatian sediments (interval "/Pt-Rs7), and the other represents the thickness of Lower Pannonian sediments (interval Rs7-Rs5). During the Late Badenian the depositional environment in the CPBS became shallower and stagnated (see Saftić et al. 2003). Under these conditions, sedimentation of pelitic clastics like marl, marly limestone, and silt as well as sporadic fine-grained sandstone, began. Such sedimentation is a result of significant decrease in the number of alluvial fans and in energy, mostly due to flattening of the entire inland area and reduction of marine areas. These conditions lasted through the Upper Badenian, Sarmatian, and most of the Lower Pannonian stages, represented by domination of calcitic marl sediments in lacustrine environments (see Malvić 2006; Malvić and Velić 2011). 


\section{Selection of input data for statistical analysis}

Thickness intervals from the Pt/Tg-Rs7 and Rs7-Rs5 maps were statistically analyzed. The maps are taken from the work of Malvić $(2003,2011)$. Both are derived from the set of paleostructural maps and show the thickness between e$\log$ markers Pt/Tg and Rs7 (Badenian and Sarmatian interval) and e-log markers Rs7 and Rs5 (Lower Pannonian interval). The maps are interpolated from well data and 26 selected and interpreted 2D seismic sections. Well data were available across the entire sub-basin, but a significant number (about 95\%) are within oil and/or gas fields, mostly located on the north side of the sub-basin (Lepavina, Jagnjedovac, Mosti, Hampovica, Cepelovac, Šandrovac, Sedlarica, Gakovo, Leticani, Galovac-Pavljani, Velika Ciglena, and Grubišno Polje). The locations of these fields, the regional exploration wells, and applied seismic sections are shown in Figs 3 and 4.

The thickness of the Pt/Tg-Rs7 interval corresponds to the Badenian and Sarmatian stages (Fig. 3). Zones of larger thicknesses can be very well observed on this map. Only normal faults were mapped. In the west is a fault with a vertical displacement of approximately $50 \mathrm{~m}$. The northern and northeastern normal faults have a maximum vertical displacement of $100 \mathrm{~m}$. The northeastern part of the study area can be characterized by the maximum isochore values of over 1,600 m. The minimum isochore values, less than $100 \mathrm{~m}$, are to the east toward Mt. Papuk, to the south around the slopes of Mt. Moslavacka, and to the southwest. In the rest of the area the thickness range is generally between 300 and $700 \mathrm{~m}$.

The Rs7-Rs5 thickness interval (Fig. 4) corresponds to sediments of Lower Pannonian age, representing a 2.2 Ma time period. The thickness of the Lower Pannonian is uniform and there is no significant maximum or minimum. Most of the mapped area is covered by isochore values of 100 to $200 \mathrm{~m}$, although the eastern part of the area is characterized by isochores of $300 \mathrm{~m}$. The Lower Pannonian sediments are thickest in the western part of the study area, where isochores reach $500 \mathrm{~m}$.

Faults in this interval are normal and reverse. Maximum vertical displacements of faults are $50 \mathrm{~m}$ (Malvić 2003). An unconformity covers most of the eastern and southeastern part of the map, in the area of Mt. Papuk and Mt. Psunj. This is the result of uplift, reduction of depositional area, and eventual erosion. This thickness map is direct proof that in the east of the Bjelovar Sub-basin the first transpressional event lasted through the Lower Pannonian.

\section{Statistical analysis of grid data derived from thickness maps}

The statistical analysis of thickness values was based on a regular grid $(500 \times$ $500 \mathrm{~m}$ ). Numerical thickness data were taken from grid nodes from each map, so that a node received the value of the closest isochore. The obtained results are shown on histograms (Figs. 5 and 6), with data selected in classes. 


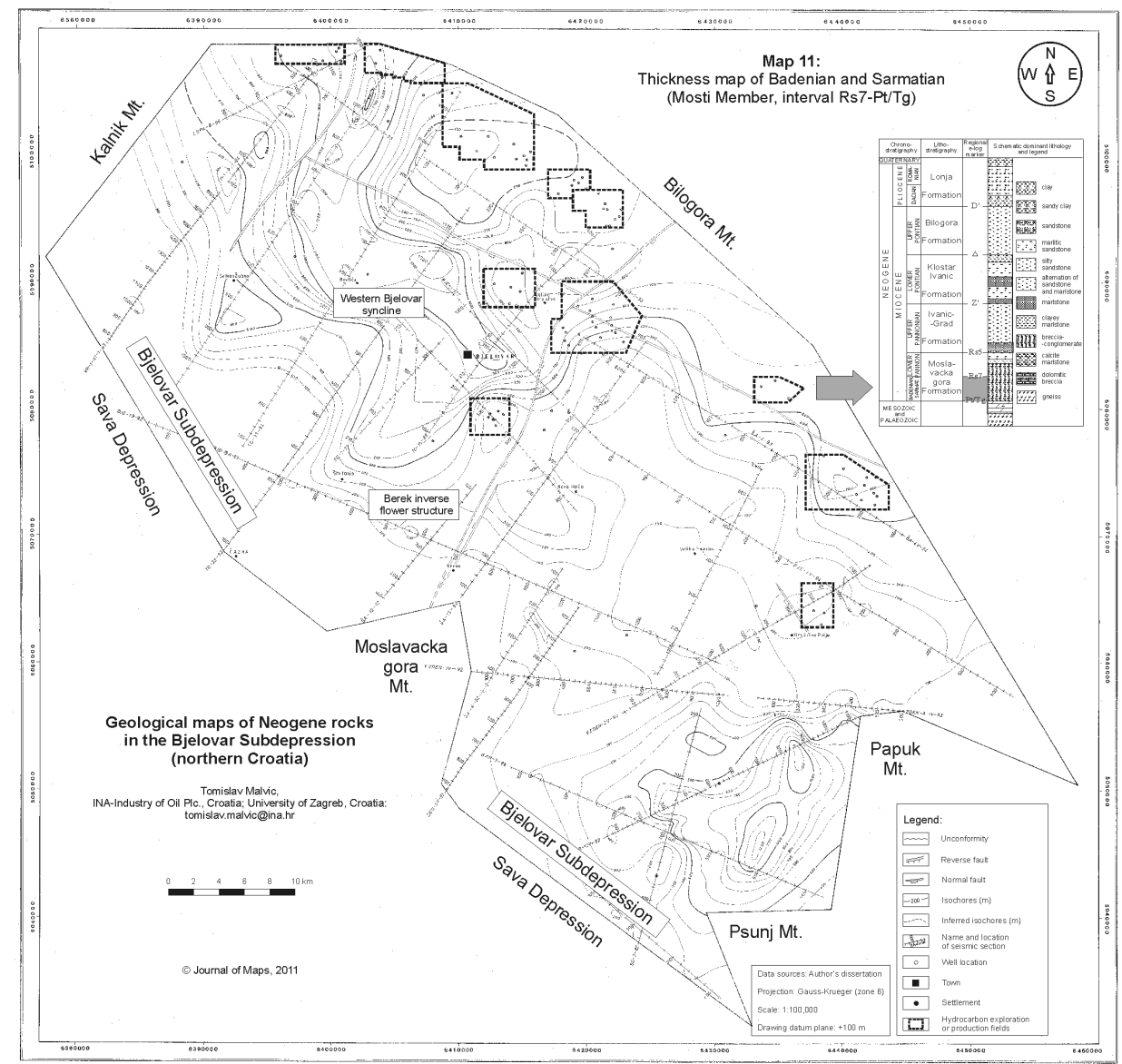

Fig. 3

Thickness map of Badenian and Sarmatian (from Malvić 2011)

In Fig. 5 the histogram indicates that the thickness distribution of Badenian and Sarmatian sediments is generally irregular, with a uniform trend. This means that the deepest parts in the Badenian paleorelief were uniformly distributed along the entire sea bottom, without regard to water depth. The origin of these smaller synclines is probably to be found in the inherited minima of Paleozoic or Mesozoic paleorelief, additionally tectonically deformed by strike-slip faults. The entire sub-basin was covered by the sea and the average thickness of BadenianSarmatian sediments is $465 \mathrm{~m}$. However, in the Early Pannonian, as a result of the first transpressional event that began in the Sarmatian, sea level decreased and consequently the sedimentation area was reduced (Fig. 4). The entire eastern part was exposed to inland erosion. Also, the sedimentation rate was reduced, as concluded from the average thickness of the Lower Pannonian of $192 \mathrm{~m}$ and the 


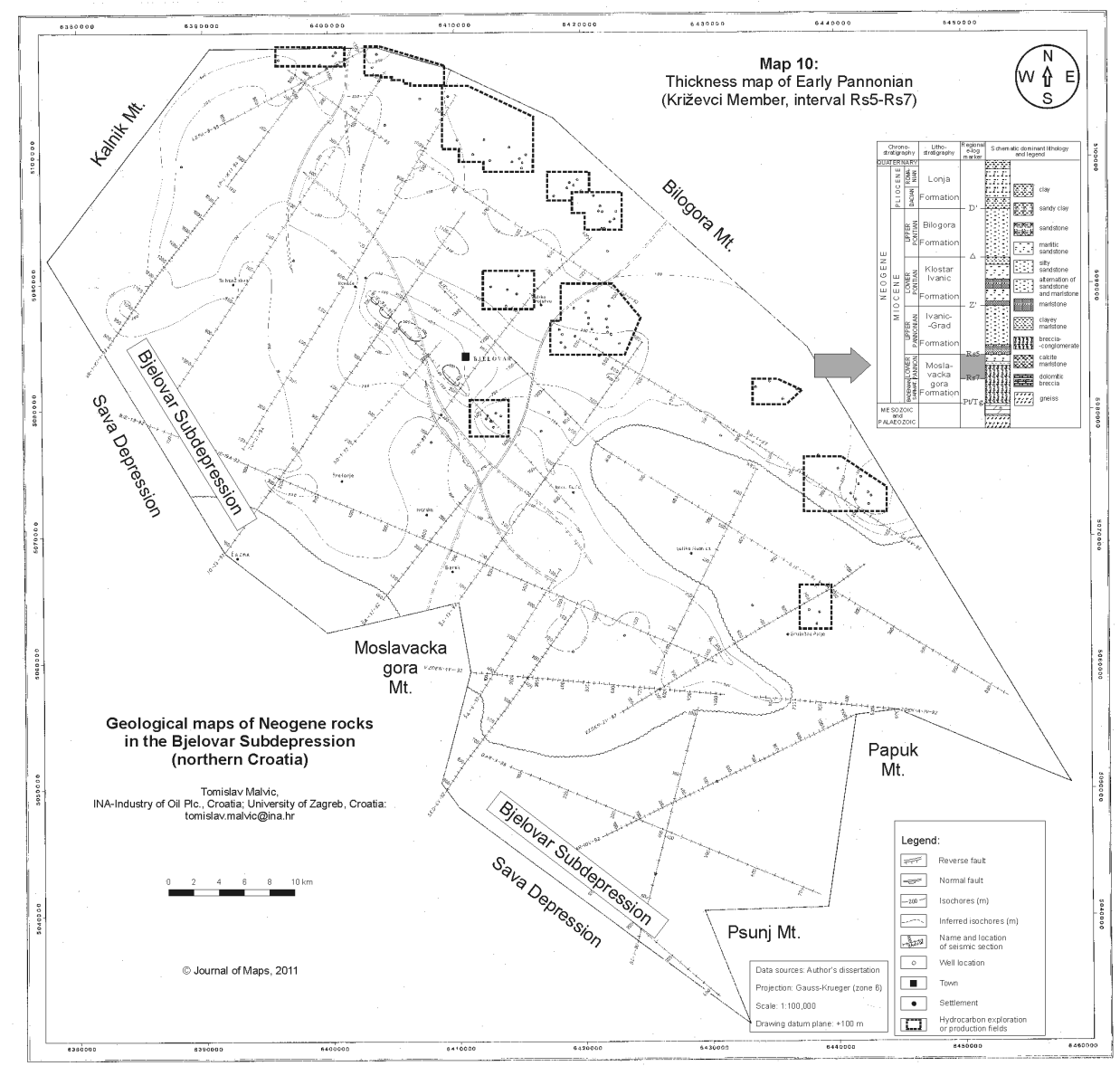

Fig. 4

Thickness map of Early Pannonian (from Malvić 2011)

predominance of a thickness of around $100 \mathrm{~m}$ (Fig. 6). Thus, these data indicated that here the uplift caused by the first transpressional event continued in the Lower Pannonian or at least in the early part of this stage. By knowing the average thickness and approximate area of the sub-basin covered by regular grid cells (each of them covers $250,000 \mathrm{~m}^{2}$ ), it was possible to calculate the approximate volumes of deposited sediments in both analyzed periods. The approximate volume of Badenian and Sarmatian sediments in the Bjelovar Subbasin is $127,875 \times 105 \mathrm{~m}^{3}$. The Lower Pannonian sediment volume is only 35,040 $\times 105 \mathrm{~m}^{3}$. 


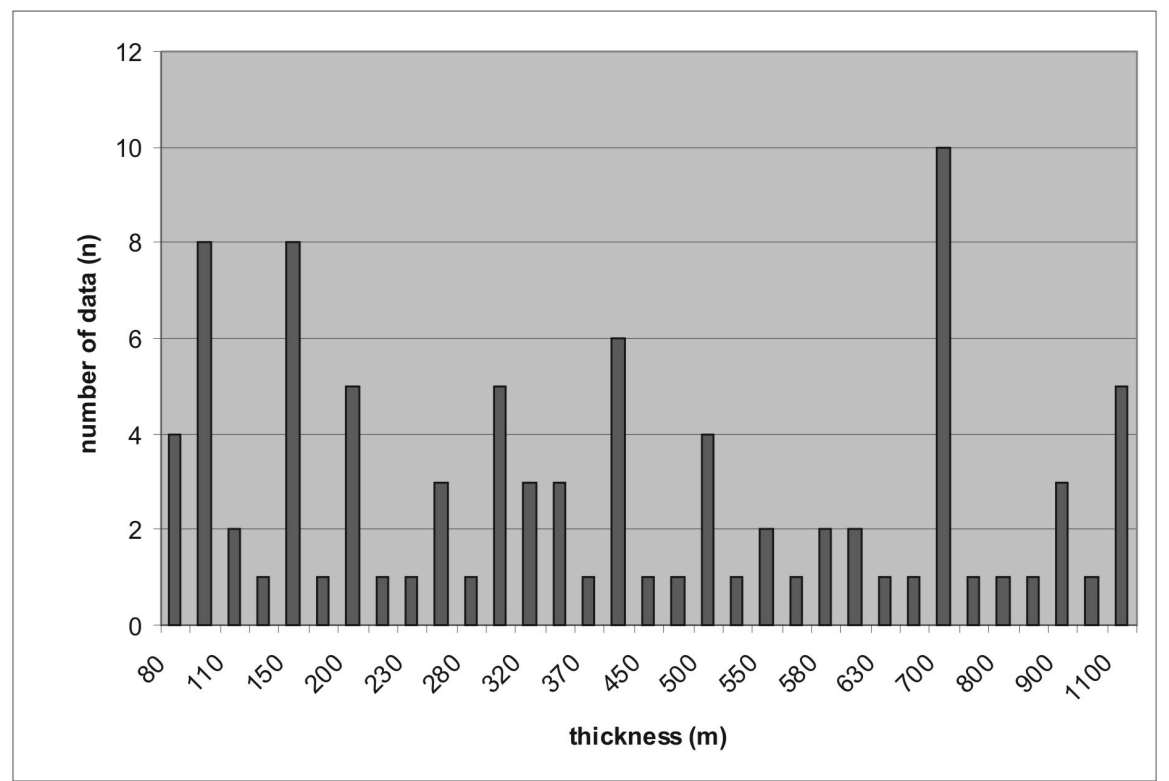

Fig. 5

Histogram of thickness values in Badenian and Sarmatian sediments of the Bjelovar Sub-basin

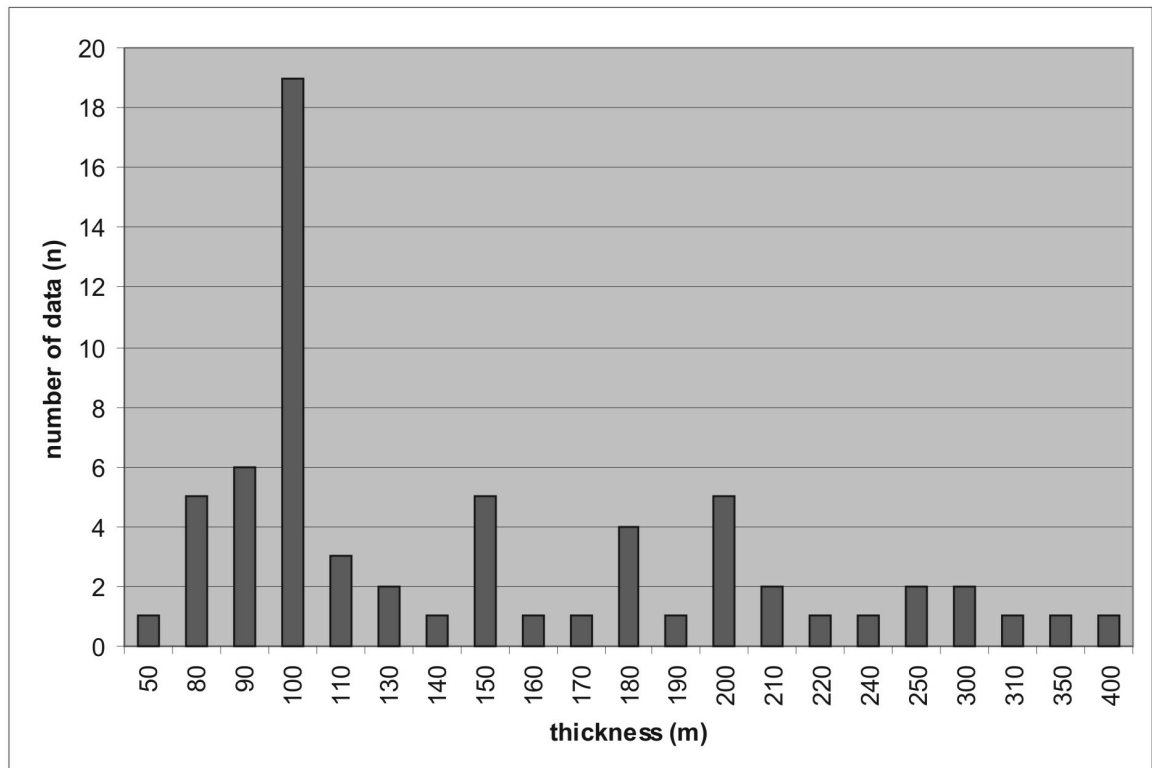

Fig. 6

Histogram of thickness values in Early Pannonian sediments of the Bjelovar Sub-basin 


\section{Conclusion}

Thickness maps for the stratigraphic intervals between the Pt/Tg-Rs7 and Rs7Rs5e-log boundary markers were statistically analyzed. Sediments in the Pt/TgRs7 interval correspond to Badenian and Sarmatian stages. Analyzed thickness values can be very easily followed on the map in Fig. 3, where the northeastern part shows the maximum isochore values. The Rs7-Rs5 interval corresponds to the Lower Pannonian stage. The thickness is much less (Fig. 4) and the differences between maximum and minimum values are more difficult to observe than on the previous map (Fig. 3), because it is mostly covered with isochore values of 100 and $200 \mathrm{~m}$. A very prominent map feature is a large unconformity that covers most of the eastern and southeastern part of the subbasin, striking along Mt. Papuk and Mt. Psunj. This is direct proof that the first transpression lasted longer in this sub-basin than in most of the CPBS. Stratigraphically, it continued into the Lower Pannonian, although it ceased at the end of the Sarmatian in other parts of the Drava and other basins.

This analysis included two chronostratigraphic intervals that do not completely correspond to the border between chronostratigraphic stages. In fact, e-log borders/markers could not distinguish the boundary between the Badenian and Sarmatian, which is crucial for interpretation of the transition from the first transtensional event to the first transpressional one. This statistical analysis provides analytical help to reach the following main conclusions:

a) Generally accepted time-boundaries between the main evolutionary stages of the CPBS, i.e., transpressional and transtensional periods, can be locally different;

b) The end of the first transpressional event in the Bjelovar Sub-basin is not defined by e-log marker Rs7, but by e-log marker Rs5; and

c) The methodology for approximate, but sufficiently precise and quick calculation of total sediment volumes in the Bjelovar Sub-basin, is provided.

Histograms in Figs 5 and 6 showed very good fit with the time-scale of regional geotectonic evolutionary events shown in Fig. 2 and in the maps (Figs 3 and 4). During the Badenian heavier sedimentation occurred in small synclines and pullaparts formed in the pre-Neogene paleorelief, as reflected in the larger thickness values. The entire sub-basin continually dropped. The average thickness was about $465 \mathrm{~m}$, including Sarmatian sediments. In the Early Pannonian, however, as a result of the first transpressional event (which started in the Sarmatian), sea level dropped and large land areas were exposed, especially in the east. Sedimentation was reduced and the average thickness decreased to less than 200 $\mathrm{m}$. In this analysis the first interval lasted more than twice as long as the second one: numerically, the Badenian and Sarmatian encompassed 4.9 Ma and the Lower Pannonian 2.2 Ma. The first interval included the entire Sarmatian (1.5 $\mathrm{Ma})$, so the larger thicknesses in the Badenian and Sarmatian are mostly the result of transtension active in the Lower and Middle Badenian. 


\section{References}

Csontos, L., L. Benkovics, F. Bergerat, J.L. Mansy, G. Worum 2002: Tertiary deformation history from seismic section study and fault analysis in a former European Tethyan margin (the MecsekVillany area, SW Hungary). - Tectonophysics, 297, pp. 51-57.

Malvić, T. 2003: Oil-geological relations and probability of new hydrocarbon discoveries in the Bjelovar subdepression [Naftnogeološki odnosi i vjerojatnost pronalaska novih zaliha ugljikovodika u Bjelovarskoj uleknini] - in English and Croatian. PhD thesis, University of Zagreb, Faculty of Mining, Geology and Petroleum Engineering, $123 \mathrm{p}$.

Malvić, T. 2006: Middle Miocene Depositional Model in the Drava Depression Described by Geostatistical Porosity and Thickness Maps (Case study: Stari Gradac-Barcs Nyugat Field). Rudarsko-geološko-naftni zbornik, 18, pp. 63-70.

Malvić, T. 2011: Geological maps of Neogene sediments in the Bjelovar Subdepression (northern Croatia). - Journal of Maps, v2011, pp. 304-317.

Malvić, T., J. Velić 2010: Relation between effective thickness, gas production and porosity in heterogeneous reservoir and example from the Molve Field, Croatian Pannonian Basin. Petroleum Geosciences, 16/1, pp. 41-51.

Malvić, T., J. Velić 2011: Neogene Tectonics in Croatian Part of the Pannonian Basin and Reflectance in Hydrocarbon Accumulations. - In: Schattner, U. (Ed.): New Frontiers in Tectonic Research: At the Midst of Plate Convergence, InTech, Rijeka, pp. 215-238.

Rögl, F. 1996. Stratigraphic correlation of the Paratethys Oligocene and Miocene. - Mitteilungen der Gesellschaft der Geologie- und Bergbaustudenten Österreich (Wien), 41, pp. 65-73.

Rögl, F. 1998. Palaeographic consideration for Mediterranean and Paratethys Seaways (Oligocene to Miocene). - Annalen des Naturhistorischen Museum, Wien, 99A, pp. 279-310.

Royden, L.H. 1988. Late Cenozoic tectonics of the Pannonian Basin System. - In: Royden, L.H., F Horváth (Eds): The Pannonian Basin. American Association of Petroleum Geologists Memoir, 45 , pp. $27-48$

Saftić, B., J. Velić, O., Sztanó, Gy. Juhász, Z. Ivković 2003: Tertiary subsurface facies, source rocks and hydrocarbon reservoirs in the SW part of the Pannonian Basin (northern Croatia and southwestern Hungary). - Geologia Croatica, 56/1, pp. 101-122.

Tari, G. 1994: Alpine tectonics of the Pannonian basin. - PhD Thesis, Rice University, Houston, 501 p.

Velić, J., M. Weisser, B. Saftić, B. Vrbanac, Z. Ivković 2002: Petroleum-geological characteristics and exploration level of the three Neogene depositional megacycles in the Croatian part of the Pannonian basin. - Nafta, 53/6-7, pp. 239-249.

Velić, J. 2007: Geologija le-išta nafte i plina. - In: Zorić, I. (Ed.) University of Zagreb, Zagreb, 342 p. 